\title{
Evidence for the Cancer Patients' Pain Management: an Integrative Review

\begin{abstract}
Suzy Ramos Rocha1, Caroline Batista de Queiroz Aquino ${ }^{1}$, Cláudia Rayanna Silva Mendes ${ }^{1}$, Míria Conceição Lavinas Santos ${ }^{2}$, Ana Fátima Carvalho Fernandes's, Camila Brasil Moreira ${ }^{3}$, Rosy Denyse Pinheiro de Oliveira ${ }^{3}$, Jordana Prado Benevides ${ }^{4}$, Ana Cristina Oliveira Barreto ${ }^{5}$, Rebeca Bandeira Barbosa ${ }^{5}$
\end{abstract}

\section{Abstract}

Background: On cancer, pain is one of the most frequent and distressing symptoms, being present in all stages of the disease. Knowing that, this study aimed to analyze the available evidence in the literature about chronic pain management by nurses in adult patients with cancer.

Methods and Results: It is an integrative review searched in the PUBMED, LILACS, CINAHL and COCHRANE databases. Nineteen studies met the inclusion criteria proposed in the study, most controlled clinical trials. The articles were analyzed and grouped into three thematic categories: health education (52.6\%), clinical practice $(36.9 \%)$ and complementary therapies (10.5\%).

Conclusion: The nurse has various means for better pain management, promoting effective assistance, minimizing possible barriers, promoting the autonomy of the patient and the ability to self-control, resulting in greater patient satisfaction.

\section{Keywords}

Chronic Pain; Nursing Care; Management of Pain.
1 Nurse. Master degree student of Nursing Department, Federal University of Ceará, Fortaleza, Ceará, Brazil.

2 Nurse. PhD. Professor at Nursing Department, Federal University of Ceará, Fortaleza, Ceará Brazil.

3 Nurse. Doctoral's student of Nursing Department, Federal University of Ceará, Fortaleza, Ceará, Brazil.

4 Nurse. Master. Professor at Paulo Petrola State School of Professional Education. Fortaleza, Ceará, Brazil.

5 Resident Nurse in Community and Family Health. Health Public School of Ceará. Fortaleza, Ceará, Brazil.

Contact information:

Suzy Ramos Rocha.

Address: Rio Araguaia Street, 699. Jardim Iracema. Federal University of Ceara, Fortaleza, CE, Brazil. Zipcode: 60340-000

” suzy_veras@hotmail.com

\section{Introduction}

On cancer, pain is one of the most frequent and distressing symptoms, being present in all stages of the disease-diagnosis, during and after treatment, in the recurrence, in advanced stages or in terminal phase 
[1], tending to increase with the progression of the disease, and may be present in $20 \%$ to $50 \%$ at the beginning of treatment and about 70\%-90\% in advanced stages [2].

In this sense, it can be a direct result of tumor invasion in $46 \%$ to $92 \%$ of cases, into nerves, organs, tissues, ligaments and fascia, or by tumor compression and organs obstruction. The suggested treatment, such as chemotherapy and radiation, can also cause damage or visceral injury, musculoskeletal injury, and nerve endings, in $5 \%$ to $20 \%$ of cases [3].

About $90 \%$ of cancer patients have chronic pain [4] and it is estimated that $42 \%$ of cancer patients are subjected to inadequate analgesia. This happens, among other factors, by professional barriers, such as lack of knowledge of the appropriate doses and collateral effects, beyond the relation of dependence and tolerance [5].

Being a subjective and complex symptom, of difficult assessment, an adequate pain management requires a thorough evaluation of its etiology, understanding of the different types and knowledge of the best therapeutic possibilities, in order to reduce its impact on the life quality of the patients. The initial careful assessment will provide a baseline for determining the subsequent interventions, which not only means the use of analgesics, but also includes action on physical, psychological, social and spiritual anguish of patients, featuring its multidimensional nature [6].

Proper preparation and nursing knowledge for pain control are fundamental to better care for patients with advanced cancer, since the inadequate assessment of pain and ignorance about the strategies available for its control are factors that can hinder management of this symptom. Thus, there are roles that must be performed by nurses, which is considered the evaluation of pain intensity, therapeutic response, side effects, and obtaining parameters and implementation of measures both pharmacological and non-pharmacological effective in the management of patients with cancer pain [7].
Considering the importance of scientific evidence-based practice, which emphasizes the use of research to guide clinical decision-making and requires the learning of skills to the use of different processes to evaluate critically and reflectively literature, combining research with professional's clinical expertise and the patient's preferences to make a decision on a specific problem [8], the present study aimed to examine the available evidence in the literature about the management of chronic pain by nurses in adult patients with cancer.

\section{Methods}

It is an Integrative Literature Review (RI). For the formulation of the RI, the following steps were covered, proposed by Mendes, Silveira and Galvão (2008): elaboration of the guiding question, sampling or literature searching, categorization of selected studies, assessment of studies included in the review, interpretation and discussion of the findings; and presentation of the review [9].

This is the guiding question of the study: which are the available evidences in the literature about chronic pain management by nurses in adult patients with cancer? The studies search took place in January and February 2016, through online access in the LILACS, PUBMED, CINAHL and COCHRANE databases, using the controlled descriptors "Pain management", "Nursing care", "Chronic pain", "Oncological nursing", which were combined in each database to ensure wide search.

The criteria established for the inclusion of studies were: original articles in English, Spanish and/ or Portuguese, published in the last 15 years, which are related to the subject, with complete methodological details and consistent results' presentation. Editorials, letters to the editor, reflective studies, reports of experience, duplicated publications, or which do not address the purpose of the review, were excluded.

After identification of the articles, it was initially held a reading of titles and abstracts, in order 
to select the theme-related publications. Then, the pre-selected articles were analyzed in their entirety. Based on inclusion and exclusion criteria presented, there were selected 19 publications to compose the sample from this review. The flowchart of selection of articles is presented in Figure 1.

Figure 1: Flow diagram preferred reporting items for integrative review.
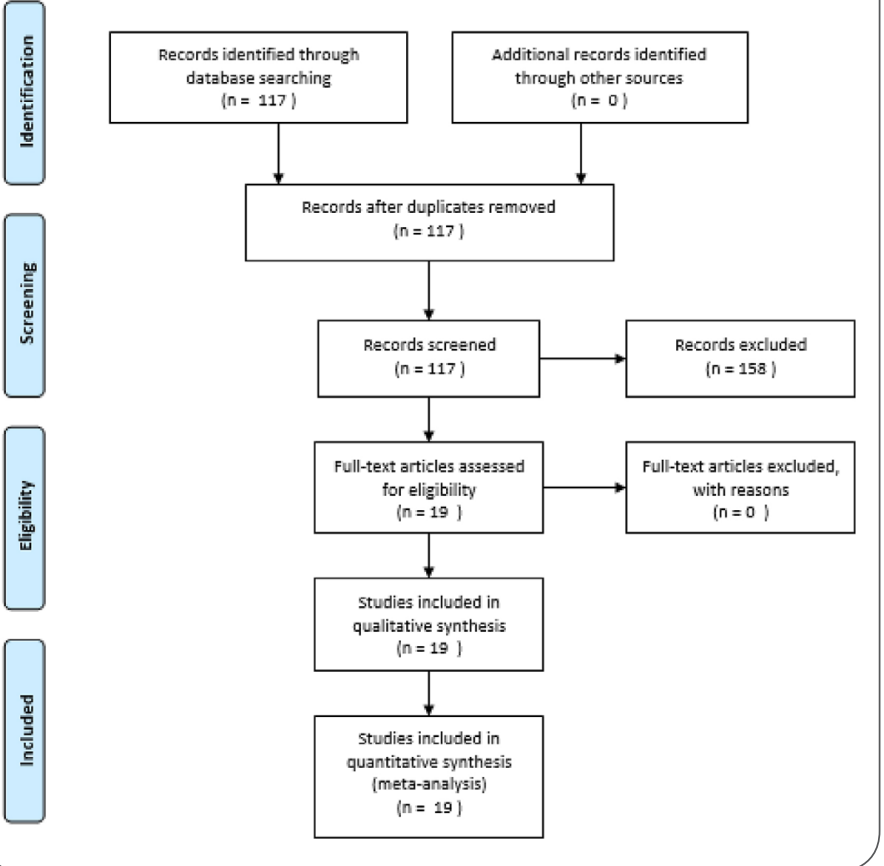

After selecting the studies, these have been categorized, extracting the necessary information that were, then, organized and incorporated in a table. In addition, it was evaluated regarding the level of evidence proposed by Fineout-Overholt et al (2010). Subsequently, evaluation and critical analysis of the articles were held and, from that, the interpretation of results, discussion and recommendations proposed has been reached, ending with the synthesis of knowledge and presentation of the review.

\section{Results}

Among the nineteen articles included in the review, it was found that 17 (89.5\%) were published in English and 2 (10.5\%) in Portuguese. As for the methodological design of the studies, 9 (47.3\%) consisted of Randomized Controlled Clinical Trial, 3 (15.8\%) almost experimental studies, 1 (5.2\%) crosssectional study, 1 (5.2\%) prospective longitudinal cohort study, 1 (5.2\%) in descriptive observational study, 3 (15.8\%) were descriptive with quantitative approach and 1 (5.2\%) exploratory-descriptive study. The characterization of the studies included in the review is present in the Table 1.

Table 1. Details of the studies included in the review (N=19). Fortaleza, CE, Brazil, 2014.

\begin{tabular}{|c|c|c|c|c|}
\hline Study & Design & $\begin{array}{l}\text { Level of } \\
\text { Evidence }\end{array}$ & Year & Category \\
\hline $\begin{array}{l}\text { Sterman et al } \\
\text { [11] }\end{array}$ & $\begin{array}{c}\text { Descriptive of } \\
\text { Quantitative } \\
\text { approach }\end{array}$ & VI & 2003 & \multirow{10}{*}{$\begin{array}{l}\text { Health } \\
\text { education }\end{array}$} \\
\hline $\begin{array}{l}\text { Schumacher et } \\
\text { al [12] }\end{array}$ & \multirow{7}{*}{ ECCR } & \multirow{7}{*}{$\|$} & 2002 & \\
\hline $\begin{array}{l}\text { Yildirim et al } \\
\text { [13] }\end{array}$ & & & 2009 & \\
\hline Yates et al [14] & & & & \\
\hline Lai et al [15] & & & 2004 & \\
\hline $\begin{array}{l}\text { Sherwood et } \\
\text { al [16] }\end{array}$ & & & 2005 & \\
\hline $\begin{array}{l}\text { Vallerand et al } \\
\text { [17] }\end{array}$ & & & 2004 & \\
\hline Herr et al [18] & & & 2012 & \\
\hline $\begin{array}{l}\text { Gustafsson e } \\
\text { Borglin [19] }\end{array}$ & \multirow[t]{2}{*}{$\begin{array}{c}\text { Quasi- } \\
\text { experimental }\end{array}$} & \multirow[t]{2}{*}{ III } & 2013 & \\
\hline Choi et al [20] & & & 2014 & \\
\hline $\begin{array}{l}\text { Kutner et al } \\
\text { [21] }\end{array}$ & ECCR & $\|$ & \multirow{2}{*}{2008} & \multirow{2}{*}{$\begin{array}{c}\text { Complementary } \\
\text { therapies }\end{array}$} \\
\hline Chang [22] & $\begin{array}{c}\text { Quasi- } \\
\text { experimental }\end{array}$ & III & & \\
\hline $\begin{array}{l}\text { Ogasawara \& } \\
\text { Hasegawa [23] }\end{array}$ & \multirow{2}{*}{$\begin{array}{c}\text { Descriptive of } \\
\text { Quantitative } \\
\text { approach }\end{array}$} & \multirow{3}{*}{$\mathrm{VI}$} & 2005 & \multirow{4}{*}{$\begin{array}{l}\text { Clinical } \\
\text { practice }\end{array}$} \\
\hline $\begin{array}{l}\text { Rustøen et al } \\
{[24]}\end{array}$ & & & \multirow{2}{*}{2013} & \\
\hline $\begin{array}{l}\text { Davies et al } \\
\text { [25] }\end{array}$ & $\begin{array}{c}\text { Observational, } \\
\text { Descriptive }\end{array}$ & & & \\
\hline $\begin{array}{l}\text { Nunes et al } \\
\text { [26] }\end{array}$ & $\mathrm{ECCR}$ & $\|$ & 2014 & \\
\hline
\end{tabular}




\begin{tabular}{|l|l|l|l|l|}
\hline \multicolumn{1}{|c|}{ Study } & Design & $\begin{array}{c}\text { Level of } \\
\text { Evidence }\end{array}$ & Year & Category \\
\hline $\begin{array}{l}\text { Nogueira et al } \\
\text { [27] }\end{array}$ & $\begin{array}{c}\text { Prospective } \\
\text { Longitudinal } \\
\text { Cohort }\end{array}$ & IV & 2014 & \\
\hline $\begin{array}{l}\text { Costa and } \\
\text { Chaves [28] }\end{array}$ & Transversal & & 2012 & $\begin{array}{c}\text { Clinical } \\
\text { practice }\end{array}$ \\
\hline $\begin{array}{l}\text { Pereira et al } \\
\text { [29] }\end{array}$ & $\begin{array}{c}\text { Exploratory- } \\
\text { descriptive }\end{array}$ & VI & & 2015 \\
\hline
\end{tabular}

\section{Health Education $(n=10)$}

Corresponds to the studies that addressed health education-related interventions in the management of cancer pain, directed to the patient, caregiver and/or healthcare professionals, whether at home, clinic or hospital.

Among the interventions that were made in the studies, 5 (26.3\%) evaluated Educational Programs, which include the implementation of scales and other features that allow a better assessment and management of pain $[11,13,15,17,19] ; 2$ (10.5\%) implemented evidence-based educational interventions, which include focus groups and application of guidelines with the professionals [18,20]; 2 (10.5\%) applied cognitive-behavioral interventions, with a focus on understanding the nature of symptoms and improving the ability to control the symptoms $[14,16]$; and 1 (5.2\%) applied daily pain management journals [12]. Table 2 highlights the main outcomes related to the studies included in the review.

\section{Additional Therapies $(n=2)$}

Correspond to studies that addressed alternative therapies such as acupuncture, massage, immersion bath, among others. Two studies were identified, which sought to evaluate the effectiveness of manual massage on pain reduction.

The first study compared single-touch massage [21], the second compared the aromatic manual massage to general manual massage with oil, noting its effect on pain, anxiety, depression and life quality in patients with advanced cancer and palliative care [22]. The massage was superior to the sim- ple-touch [21], while the aromatic manual massage superimposed the manual massage with oil, with important effect in reducing pain and depressive symptoms [22].

\section{Clinical Practice $(n=7)$}

Corresponds to studies that addressed clinical interventions to patients by nurses, such as pain management, nursing diagnoses related to oncology patients with acute or chronic pain, and patient approach.

As for the interventions that were carried out, a study conducted in Europe evaluated the knowledge of nurses regarding the assessment and therapeutic approach to pain through the use of questionnaires [24]. Another study identified the nursing diagnoses and interventions related to pain in cancer patients [23]. Many studies have assessed the intensity of pain and its interference in daily activities, the number of episodes, used therapeutic approaches and the effectiveness of these approaches [25-29]. It was also observed, as compared to the use of morphine as first choice for analgesia relative to the group following the analgesic scale (starting treatment with nonopioid, followed by weak opioid and finally potent opioid) [26].

Among the significant findings related to pain assessment, it was found that $65 \%$ of patients were taking opioid + analgesics for pain control, and had a 7 average of pain intensity [27]. It showed an average of 6.7 of pain intensity in patients who reported pain. Among these patients, only $63 \%$ took drugs as prescription, being $46.6 \%$ analgesics, $8 \%$ morphine, $8 \%$ tramadol and $8 \%$ codeine [28].

\section{Discussion}

This review has shown skills that can be performed by nurses for pain management that go beyond the conventional administration of analgesics and opioids. The approach of health education programs and alternative health practices reinforces the dynamic 
role of the nurse in conducting measures for the control of pain, including patient's empowerment to self-care and self-management of pain.

However, some aspects have limited this review, highlighting the lack of analysis on the included studies regarding the type of cancer, staging of disease and socio-demographic characteristics, able to interfere directly in the pain intensity and management. In addition, there were no systematic reviews and meta-analyzes on the subject.

Results of health education for nurses showed that the professionals who participated in the programs reported greater confidence to assess the pain, to have a more effective attitude to management this symptom, and they also reported reduction of barriers [17-19]. As an effective result, higher patient satisfaction was obtained, which was caused by two aspects. The first one is related to better pain management, with an approach, evaluation, most appropriate measurement and intervention; the second one is related to an accurate orientation in relation to self-care, focused in rest, comfort, emotional state and patient-controlled analgesia. [14, 16-17].

Health education with professional nurses portray an evidence-based care model, combining scientific research with professional practice, and should be a positive process and accepted by the patient [30]. Therefore, various means have been used, including structured educational programs in pain, pain journals, pain measurement scales, cognitive-behavioral interventions, as well as targeted self-management programs.

Educational programs with focus on the pain experience "in cancer" results in improvements in life quality and pain intensity; adjustment in the conceptions and beliefs about cancer pain and its control, increased adherence to drug therapy and greater acceptance of non-pharmacological means [31]. So, information and education can make the difference between effective and ineffective management of pain [32].
The pain should be considered the "fifth vital sign" and can be manifested in many ways. Therefore, it should be evaluated regularly and systematically with validated assessment tool, with scales that quantify and qualify the painful feeling of accurate manner in order to properly plan anti-algic therapy [33]. In cancer, this symptom is dynamic and can change in response to treatment or disease progression. Thus, it should establish a baseline measurement before any intervention, identifying the location, intensity, duration and frequency of painful episodes and the factors that increase or decrease their intensity, then it should be re-evaluated after each intervention in order to assess their effectiveness and the need for change in the treatment regimen, to better recovery and quality of life of the patient. [34].

Massage was the alternative therapy used for pain management in both studies that make up this category and show effective results in both pain and mood improvement. Research points out the effectiveness of massage as an adjunct technique to relieve pain caused by cancer, as well as reducing fatigue, nausea, anxiety, depression and stress indicators symptoms. It's also important to ensure that individuals with cancer understand the improvements in physical and psychological symptoms (pain, nausea, anxiety), which can be achieves with the application of periodic massages [35].

One of the results observed in this review was the use of diagnoses and nursing interventions in patients with terminal cancer [22]. The use of nursing diagnosis directs nursing care to the needs of each client, facilitates the choice of the most appropriate interventions, registers objectively customer reactions and allows subsequent evaluation of nursing care [36].

In a study carried out with hospitalized patients, there were evidenced values similar to those found in articles that make up this category, in which the average rating of pain intensity of 76 patients was 5.3 , considering a scale from 0 to 10 . Most patients 
(71.87\%) agreed that received pain medication in the last 24 hours. However, only 18 patients (25\%) reported $50 \%$ or less pain relief after receiving pain treatments or medications [37].

On analgesia scale, there is a sequence that should be considered when administering analgesics. It must start with non-opioid drugs and, if pain is not controlled, opioids must be used for mild to moderate pain. If pain remains uncontrolled, an opioid drug is used for moderate to severe pain. In every step on the scale, adjuvant drug may be added [38].

Nurses play an important role in the management of medicines. This includes ensuring that patients understand what medications they are taking and what the likely side effects are. When administering analgesics, nurses should also be aware of how to progress to the next level of stronger analgesia, in case of pain advance, or how to increase doses when there is failure in the final dose [39].

Therefore, it reinforces the importance of the nurse's role in pain management in its various forms, from health educational to the implementation of interventions that are informed by the systematization of their assistance, with emphasis on clinical practice and use of complementary therapies. Therefore, we recommend the use of tools to assess pain, the use of nursing diagnoses for rating this symptom, the use of drugs to his relief, according to the intensity and the importance of having more studies in this approach to enrich the management field of pain in cancer patients.

\section{Conclusion}

After the analysis of evidence, it was observed the existence of various techniques for the management of chronic pain in cancer patients, including health education, clinical practices and complementary therapies. New clinical practices, aimed at improving the assistance, were also highlighted in the studies, with emphasis on the analysis of nursing diagnoses in patients with terminal cancer, which leads to awareness of the shortage of new diagnoses that are suited to this class of patients; it searches for a more efficient form of pain analysis, but with reference to the cessation of pain and patient satisfaction in handling this.

\section{References}

1. Stark L, Tofhagen C, Visovsky C, McMillan S. The symptom experience of patients with cancer. J Hosp Palliat Nurs. 2012; 14: 61-70.

2. Doyle N. Cancer survivorship: evolutionary concept analysis. JAN. 2008; 62: 499-509.

3. Macintyre P, Scott $D$, Schug S. Acute Pain Management: Scientific Evidence. 3th ed. Melbourne: Australian and New Zealend College of Anaesthetists and Faculty of Pain Medicine; 2010.

4. Handy CR, Krudy C, Boulis N. Gene therapy: a potential approach for cancer pain. Pain Res Treat. 2011; 2011: 1-12.

5. Rana S, Gupta R, Chaudhary P, Khurana D, Mishra S, Bhatnagar $S$. Cancer pain management: basic information for the young pain physician. Indian J Palliat Care. 2011;17: 127-30.

6. Wengström Y, Geerling J, Rustøen T. European Oncology Nursing Society breakthrough cancer pain guidelines. Eur J Oncol Nurs. 2014;18: 127-31.

7. Garcia A, Whitehead D, Winter HS. Oncology nurses' perception of cancer pain: A qualitative exploratory study. Nurs Prax N Z. 2015; 31: 27-33.

8. Ferreira AM, Andrade D. Revisão integrativa da técnica limpa e estéril: consensos e controvérsias na realização de curativos. Acta Paul Enferm. 2008; 21: 117-21.

9. Mendes KDS, Silveira RCCP, Galvão CM. Revisão integrativa: Método de pesquisa para a incorporação de evidências na saúde e na enfermagem. Texto \& Contexto Enferm. 2008; 17 : 758-64

10. Fineout-overholt E, Melnyk BM, Stillwell SB, Williamson KM. Evidence-based practice step by step: Critical appraisal of the evidence: part I. Am J Nurs. 2010; 110: 47-52.

11. Sterman E, Gauker S, Krieger J. A comprehensive approach to improving cancer pain management and patient safisfaction. Oncol Nurs Forum. 2003; 30(5): 857-64.

12. Schumacher KL, Koresawa S, West C, Dodd M, Paul SM, Koo $P$, et al. The usefulness of a daily pain management diary for outpatients with cancer-related pain. Oncol Nurs Forum. 2002; 29: $1304-13$ 
13. Yildirim YK, Cicek F, Uyar M. Effects of pain education program on pain intensity, pain treatment satisfaction, and barriers in Turkish cancer patients. Pain Manag Nurs. 2009; 10: 220-8.

14. Yates $P$, Edwards $H$, Nash $R$, Aranda S, Purdie D, Walsh A, et al. A randomized controlled trial of a nurse-administered educational intervention for improving cancer pain management in ambulatory settings. Patient Educ Couns. 2004; 53: 227-37.

15. Lai YH, Guo SL, Keefe FJ, Tsai SL, Chien CC, Sung YC, et al. Effects of brief pain education on hospitalized cancer patients with moderate to severe pain. Support Care Cancer. 2004; 12: 645-52.

16. Sherwood P, Given BA, Given CW, Champion VL, Doorenbos $A Z$, Azzouz $F$, et al. A cognitive behavioral intervention for symptom management in patients with advanced cancer. Oncol Nurs Forum. 2005; 32: 1190-8.

17. Vallerand AH, Riley-Doucet C, Hasenau SM, Templin T. Improving cancer pain management by homecare nurses. Oncol Nurs Forum. 2004; 31: 809-16.

18. Herr K, Titler M, Fine PG, Sanders S, Tang X, Swegle J, et al. The effect of a Translating Research into Practice (TRIP) - cancer intervention on cancer pain management in older adults in hospice. Pain Med. 2012; 13: 1004-17

19. Gustafsson M, Borglin G. Can a theory-based educational intervention change nurses' knowledge and attitudes concerning cancer pain management? A quasi-experimental design. BMC Health Serv Res. 2013; 13: 328-33.

20. Choi M, Kim HS, Chung SK, Ahn MJ, Yoo JY, Park OS, et al. Evidence-based practice for pain management for cancer patients in an acute care setting. Int J Nurs Pract. 2014; 20: 60-69.

21. Kutner JS, Smith MC, Corbin L, Benton K, Mellis BK, Beaty B, et al. Massage therapy versus simple touch to improve pain and mood in patients with advanced cancer: a randomized trial. Ann Intern Med. 2008; 149: 369-79.

22. Chang SY. Effects of aroma hand massage on pain, state anxiety and depression in hospice patients with terminal cancer. Taehan Kanho Hakhoe Chi. 2008; 38: 493-502.

23. Ogasawara C, Hasegawa T, Kume Y, Takahashi I, Katayama $Y$, Andoh $M$, et al. Nursing diagnoses and interventions of Japanese patients with end-stage breast cancer admitted for different care purposes. Int J Nurs Terminol Classif. 2005; 16: 54-64.
24. Rustøen T, Geerling JI, Pappa T, Weisse I, Williams SC, Zavratnik $B$, et al. A European survey of oncology nurse breakthrough cancer pain practices. Eur J Oncol Nurs. 2013; 17: 95-100.

25. Davies A, Buchanan A, Zeppetella G, Zucco F, Nauck F, Filbet $M$, et al. Breakthrough Cancer Pain: An Observational Study of 1000 European Oncology Patients. J Pain Symptom Manage. 2013; 46: 619-28.

26. Nunes BC, Garcia JBS, Sakata RK. Morfina como primeiro medicamento para tratamento da dor de câncer. Braz J Anesthesiol. 2014; 64: 236-40.

27. Nogueira RTE, Vieira EBM, Sousa LHA, Garcia JBS. Difficult situation in cancer pain: breakthrough pain. Rev Dor. 2014; 15(1): 41-47.

28. Costa AIS, Chaves MD. Pain in cancer patients under chemotherapy. Rev Dor. 2012; 13: 45-49.

29. Pereira DTS, Andrade LL, Agra G, Costa MML. Condutas terapêuticas utilizadas no manejo da dor em oncologia. J Res Fundam Care. 2015; 7: 1883-90.

30. Buchanan A, Geerling J, Davies A. Breakthrough cancer pain: the role of the nurse. Int J Palliat Nurs. 2014; 20: 126-30.

31. Ernst E. Massage therapy for cancer palliation and supportive care: a systematic review of randomised clinical trials. Support Care Cancer. 2009; 17: 333-37.

32. Chapman S. Cancer pain part 2: assessment and management. Nursing Standard. 2012; 26(48): 44-49.

\section{Publish in International Archives of Medicine}

International Archives of Medicine is an open access journal publishing articles encompassing all aspects of medical science and clinical practice. IAM is considered a megajournal with independent sections on all areas of medicine. IAM is a really international journal with authors and board members from all around the world. The journal is widely indexed and classified Q2 in category Medicine. 